\title{
Game changers in pediatric cancer
}

\author{
Jane de Lartigue, $\mathrm{PhD}$
}

A

lthough there have been significant improvements in patient outcomes for some forms of pediatric cancer, progress has been painfully slow for others. An increasing understanding of pediatric cancers is highlighting the unique molecular drivers and challenging the assumption that drugs developed in adults can be applied to children and young adults. Here, we discuss gamechanging therapeutic advances and a shifting view of childhood cancers.

\section{Unique genomic background}

Although pediatric cancers are rare, representing just $1 \%$ of all new cancers diagnosed annually in the United States, they are the second leading cause of death in children aged 1 to 14 years. There are many different histological tumor types under the umbrella of childhood cancers, of which the most common are leukemias, central nervous system tumors, and lymphomas (Figure 1). ${ }^{1,2}$

Significant progress has been made in the treatment of certain pediatric cancers in recent decades, exemplified by pediatric acute lymphoblastic leukemia (ALL), which has been transformed from a virtually incurable cancer to one in which 5 -year survival rates now reach up to $90 \%$. In other forms of pediatric cancer, however, survival rates have stagnated and little progress has been made in the development of effective new therapies. $^{3}$

Because of their rarity, pediatric cancers are difficult to study and adequate enrollment of children in clinical trials can be chal-

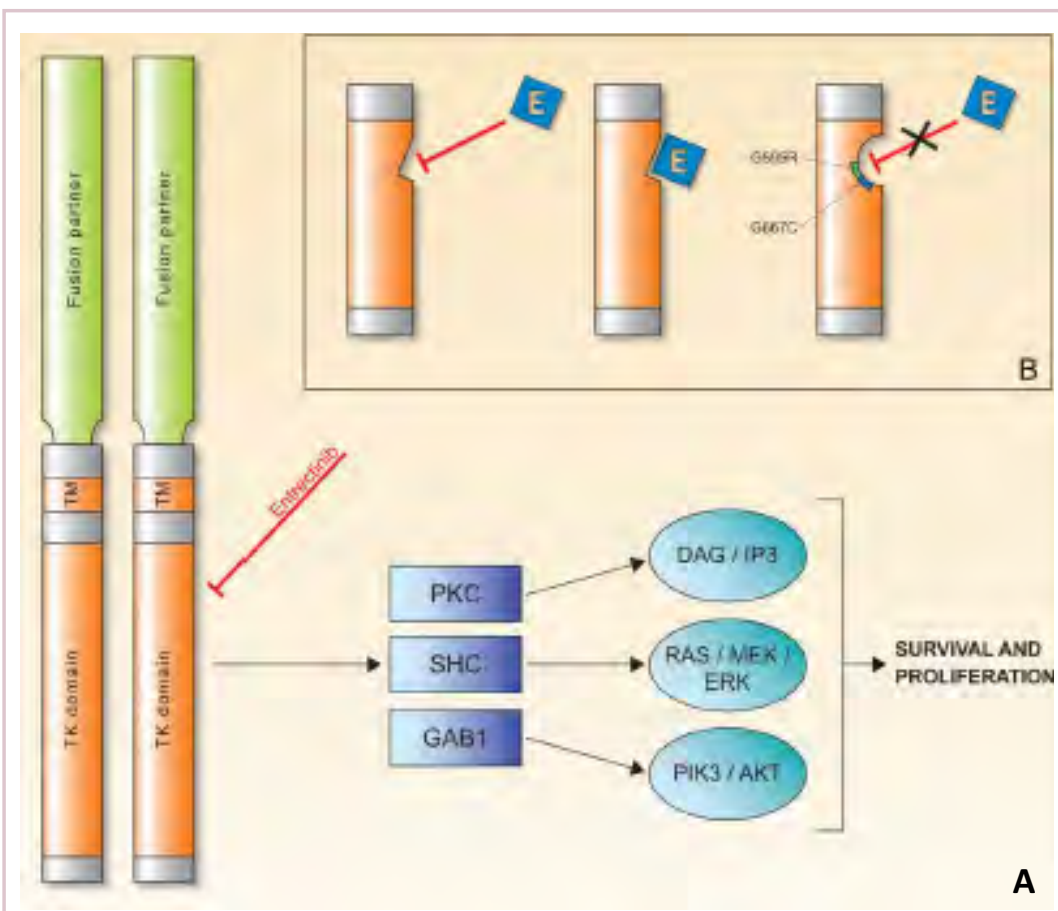

FIGURE 1 Targeting TRK fusions. ${ }^{16}$ The tropomyosin receptor kinases are a family of transmembrane proteins, highly expressed in neuronal tissue, which control many cancer hallmark processes through the activation of several downstream signaling pathways. Gene fusions involving the NTRK genes are being identified in an evergrowing list of tumor types. The fusions drive constitutive activation of these tyrosine kinases and the cellular processes they regulate. A number of TRK inhibitors have been developed that are designed to block the activity of TRK fusions, including entrectinib (A). Several mechanisms of resistance to TRK inhibitors have already been identified (B). 


\begin{tabular}{|c|c|c|c|}
\hline Drug & Manufacturer & Mechanism of action & Approved pediatric indication \\
\hline Tisagenlecleucel (Kymriah) & Novartis & $\begin{array}{l}\text { CD19-targeted CAR T-cell } \\
\text { therapy }\end{array}$ & $\begin{array}{l}\text { Relapsed/refractory B-cell ALL after } 2 \text { or more prior } \\
\text { treatments }\end{array}$ \\
\hline Pembrolizumab (Keytruda) & Merck & PD1-targeted mAb & $\begin{array}{l}\text { Relapsed/refractory cHL after } 3 \text { or more prior treatments } \\
\text { Relapsed/refractory } \mathrm{dMMR} / \mathrm{MSI} \text {-high solid tumors } \\
\text { Relapsed/refractory } \mathrm{PMBCL} \text { after } 2 \text { or more prior } \\
\text { treatments }\end{array}$ \\
\hline Ipilimumab (Yervoy) & Bristol-Myers Squibb & CTLA4-targeted mAb & Metastatic melanoma \\
\hline Blinatumomab (Blincyło) & Amgen & CD19-targeted BiTE & $\begin{array}{l}\text { Relapsed/refractor B-cell ALL regardless of Philadelphia } \\
\text { chromosome status }\end{array}$ \\
\hline $\begin{array}{l}\text { Gemtuzumab ozogamicin } \\
\text { (Mylotarg) }\end{array}$ & Pfizer & CD33-targeted ADC & Relapsed/refractory CD33-positive AML \\
\hline Dinutuximab (Unituxin) & United Therapeutics & GD2-targeted mAb & High-risk neuroblastoma \\
\hline
\end{tabular}

ADC, antibody-drug conjugate; ALL, acute lymphoblastic leukemia; AML, acute myeloid leukemia; BiTE, bispecific T-cell engager; CAR, chimeric antigen receptor; cHL, classical Hodgkin lymphoma; CML, chronic myeloid leukemia; CTLA-4, cytotoxic T lymphocyte antigen-4; dMMR, defective mismatch repair; mÁ, monoclonal antibody; mCRC, metastatic colorectal cancer; MSI, microsatellite instability; PD-1, programmed cell death protein-1; PMBCL, primary mediastinal large B-cell lymphoma

mutational burden in pediatric cancers and the mechanisms of oncogenesis are also quite different; adult tumors can develop from a series of acquired gene mutations, but pediatric tumors tend to develop from a single catastrophic event. ${ }^{4,5}$

Even the same type of cancer in a pediatric and adult patient can be quite different, with very different underlying molecular mechanisms. In a recent genomic analysis of different types of pediatric cancer by researchers at $\mathrm{St}$ Jude's Children's Research Hospital, less than half of the identified mutated genes were found to be similar to those found in adult patients. ${ }^{6}$

\section{A 'magic bullet'?}

Chromosomal rearrangements are common in pediatric cancers. This type of molecular abnormality can result in a fusion of 2 different genes when the chromosome breaks apart and the pieces join back together in a muddled order. If the genetic code fuses in a manner that is "readable" by the cell, then it can drive aberrant activation of one or both genes. ${ }^{7}$ Gene fusions often involve kinase enzymes that are essential players in cell signaling pathways regulating hallmark cancer processes, such as unchecked cell proliferation. The fusion drives the constitutive activation of the kinase and, thus, these downstream signaling pathways.

One of the first chromosomal rearrangements linked to cancer, BCR-ABL1 - more commonly known as the Philadelphia chromosome - results in aberrant activation of the ABL1 kinase. It is present in nearly all cases of chronic myeloid leukemia (CML) and 3\% to $5 \%$ of patients with ALL, and thus became the central focus of targeted drug development. Imatinib was initially approved by the US Food and Drug Administration (FDA) in 2001 for the treatment of adult patients with CML and had such a significant impact on the treatment landscape that it made the cover of Time magazine as a "magic bullet" in the war on cancer. ${ }^{8}$

Approval was expanded into pediatric patients in 2006 and for pediatric patients with ALL in 2013. However, as with the use of most kinase inhibitors, tumors can evolve under the selective pressure of treatment, developing additional molecular abnormalities that drive resistance. ${ }^{9}$

Next-generation multikinase inhibitors that more potently inhibit the BCR-ABL1 fusion protein have been developed to provide additional treatment options for patients who become resistant to imatinib. Dasatinib and nilotinib are among several drugs that have recently been approved for pediatric cancer therapy (Table 1). Both therapies were approved to treat children with Philadelphia chromosome-positive CML in the chronic phase in either the front- or second-line setting after failure of imatinib.

The approval of dasatinib was based on data from 97 patients across 2 trials, 51 of whom were newly diagnosed and 46 previously treated with imatinib. Most of the patients were treated with dasatinib $60 \mathrm{mg} / \mathrm{m}^{2}$ once daily. After 2 years of follow-up, more than $95 \%$ of newly diagnosed patients and $82.6 \%$ of relapsed/refractory patients had complete cytogenetic response. ${ }^{10}$ 
TABLE 2 Ongoing clinical trials of targeted therapies in pediatric cancers

\begin{tabular}{|c|c|c|c|}
\hline Drug & Developer & Mechanism of action & $\begin{array}{l}\text { Most advanced stage of clinical development in the } \\
\text { pediatric setting (ClinicalTrials.gov identifier) }\end{array}$ \\
\hline LOXO-195 & Loxo & TRK inhibitor & $\begin{array}{l}\text { Phase } 1 / 2 \text { in relapsed/refractory NTRK fusion-positive can- } \\
\text { cers (NCT03215511) }\end{array}$ \\
\hline Dabrafenib (Tafinlar) & Novartis & BRAF inhibitor & $\begin{array}{l}\text { Phase } 2+\text { trametinib in relapsed/refractory glioma } \\
\text { (NCT02684058) }\end{array}$ \\
\hline Trametinib (Mekinist) & Novartis & MEK inhibitor & $\begin{array}{l}\text { Phase } 2 \text { in relapsed/refractory glioma or neurofibroma } \\
\text { (NCT03363217) }\end{array}$ \\
\hline Crizotinib (Xalkori) & Pfizer & ALK/MET/ROS1 inhibitor & $\begin{array}{l}\text { Phase } 2+\text { combination chemotherapy in newly diagnosed } \\
\text { ALCL (NCT01979536) }\end{array}$ \\
\hline Ceritinib (Zykadia) & Novartis & ALK inhibitor & $\begin{array}{l}\text { Phase } 1 / 2+\text { brentuximab vedotin in ALK-positive ALCL } \\
\text { (NCT02729961) }\end{array}$ \\
\hline Lorlatinib & Pfizer & ALK/ROS1 inhibitor & $\begin{array}{l}\text { Phase } 1 \text { in relapsed/refractory ALK-positive neuroblastoma } \\
\text { (NCT03107988) }\end{array}$ \\
\hline Dasatinib (Sprycel) & Bristol-Myers Squibb & Multi-targeted kinase inhibitor & Phase 3 in newly diagnosed ALL (NCT03020030) \\
\hline Nilotinib (Tasigna) & Novartis & Multi-targeted kinase inhibitor & $\begin{array}{l}\text { Phase } 1 / 2+\text { vinblastine in relapsed/refractory low-grade } \\
\text { glioma (VINILO; NCTO1884922/NCTO1887522) }\end{array}$ \\
\hline
\end{tabular}

ALCL, anaplastic large cell lymphoma; ALK, anaplastic lymphoma kinase; ALL, acute lymphoblastic leukemia; CNS, central nervous system; FGFR, fibroblast growth factor receptor; MEK, mitogen-activated protein kinase; NHL, non-Hodgkin lymphoma; TRK, tropomyosin receptor kinase

Nilotinib was approved on the basis of findings from 2 clinical trials including 69 patients - 1 trial involving patients who were refractory to or relapsed after dasatinib and imatinib treatment, and 1 that included both relapsed/ refractory and newly diagnosed patients. Patients received nilotinib $230 \mathrm{mg} / \mathrm{m}^{2}$ twice daily, rounded to the nearest $50-\mathrm{mg}$ dose, in 28-day cycles. By cycle 12 , the cumulative major molecular response rate (MMR) was $47.7 \%$ in patients with relapsed/refractory disease, and 64\% in newly diagnosed patients. ${ }^{11}$ Clinical trials of both drugs in the pediatric setting are ongoing.

\section{Other prominent gene fusions}

Gene fusions involving the anaplastic lymphoma kinase (ALK) occur in patients with non-small-cell lung cancer and ALK inhibitors have provided an effective new treatment option for patients whose tumors display this abnormality.

ALK fusions are also a prominent feature of several kinds of pediatric cancers and ALK inhibitors offer promise in this setting. ${ }^{7,12}$ An NPM-ALK fusion is found in $90 \%$ of pediatric anaplastic large cell lymphoma (ALCL) cases, ${ }^{13}$ whereas a variety of ALK fusions are found in up to half of patients with inflammatory myofibroblastic tumor (IMT), a rare form of soft tissue sarcoma. ${ }^{14} \mathrm{ALK}$ inhibitors are being tested in a variety of clinical trials in pediatric patients (Table 2).

The results of a small phase 1 study of crizotinib in pediatric patients with ALK-positive ALCL $(n=26)$ or IMT $(n=14)$ were recently published. ALCL patients received crizotinib at a dose of $165 \mathrm{mg} / \mathrm{m}^{2}$, while IMT patients were given 100,165 , or $280 \mathrm{mg} / \mathrm{m}^{2}$. For the latter, the results were presented as a pooled cohort since safety and efficacy data were similar across dose levels. The overall response rate (ORR) was $83 \%$ for patients with ALCL and $86 \%$ for those with IMT. Grade 3/4 adverse events occurred in $83 \%$ and $71 \%$ of patients, respectively, and most commonly involved reduced neutrophil count. ${ }^{15}$

Most recently and perhaps most promisingly, fusions involving the neurotrophic tropomyosin receptor kinase $(N T R K)$ gene have generated significant buzz. There are 3 NTRK genes, NTRK1, 2, and 3, which encode the TRKA, $\mathrm{TRKB}$, and TRKC proteins, respectively. 
To date, 22 different partner genes have been identified that can fuse with the NTRK genes and, as with other kinase fusions, drive constitutive activation of the receptor proteins and downstream oncogenic signaling pathways, including the mitogen-activated protein kinase (MAPK) pathway (Figure 2).

NTRK fusions are being identified in an evergrowing number of cancer types, but are typically found in a small percentage of patients. However, in certain rare pediatric tumors, including congenital infantile fibrosarcoma and papillary thyroid cancer, they are found at much higher frequencies.

TRK inhibitors have been developed to target the fusion proteins and, given the spread of NTRK fusions across different types of cancers, they offer the most substantial promise as the next tumor agnostic cancer therapy - to treat patients based on the shared presence of a molecular aberration, irrespective of the type of cancer. ${ }^{16}$

The ongoing SCOUT trial is evaluating larotrectinib (LOXO-101) in pediatric patients. Among 24 patients (17 with NTRK fusions and 7 without) with infantile fibrosarcoma (47\%), soft tissue sarcoma $(41 \%)$ or papillary thyroid cancer $(12 \%)$, the ORR was $93 \%$, including complete response (CR) in $13 \%$ of patients. ${ }^{17}$

Preliminary results from an ongoing phase $1 / 2$ study of entrectinib in pediatric patients with extracranial solid tumors were also recently presented at the annual meeting of the American Society for Clinical Oncology (ASCO). Among 15 evaluable patients enrolled to date, 3 have NTRK fusions and all experienced an objective response, with 1 (a patient with IMT) ongoing at 10 months. ${ }^{18}$

\section{CAR T cells transformative in ALL}

A variety of different types of immunotherapy have been tested in patients with pediatric cancers. In general, immunotherapy has proved less effective than in adult cancers, possibly because of the lower tumor mutation burden in pediatric cancers, which means there are likely fewer cancer antigens to provoke an antitumor immune response.

There are notable exceptions among the disappointments, however, and most exciting is the development of chimeric antigen receptor (CAR) $\mathrm{T}$ cells. CAR T cells fall into a category of immunotherapy known as adoptive cell therapy (ACT), in which immune cells are harvested from a patient and grown outside the body to increase their numbers before being reinfused into the patient.

In the case of CAR T-cell therapy, the cells are genetically engineered to express a CAR that endows them with tumor-targeting capabilities. To date, the development of CAR T cells has focused on the use of the CD19 antigen

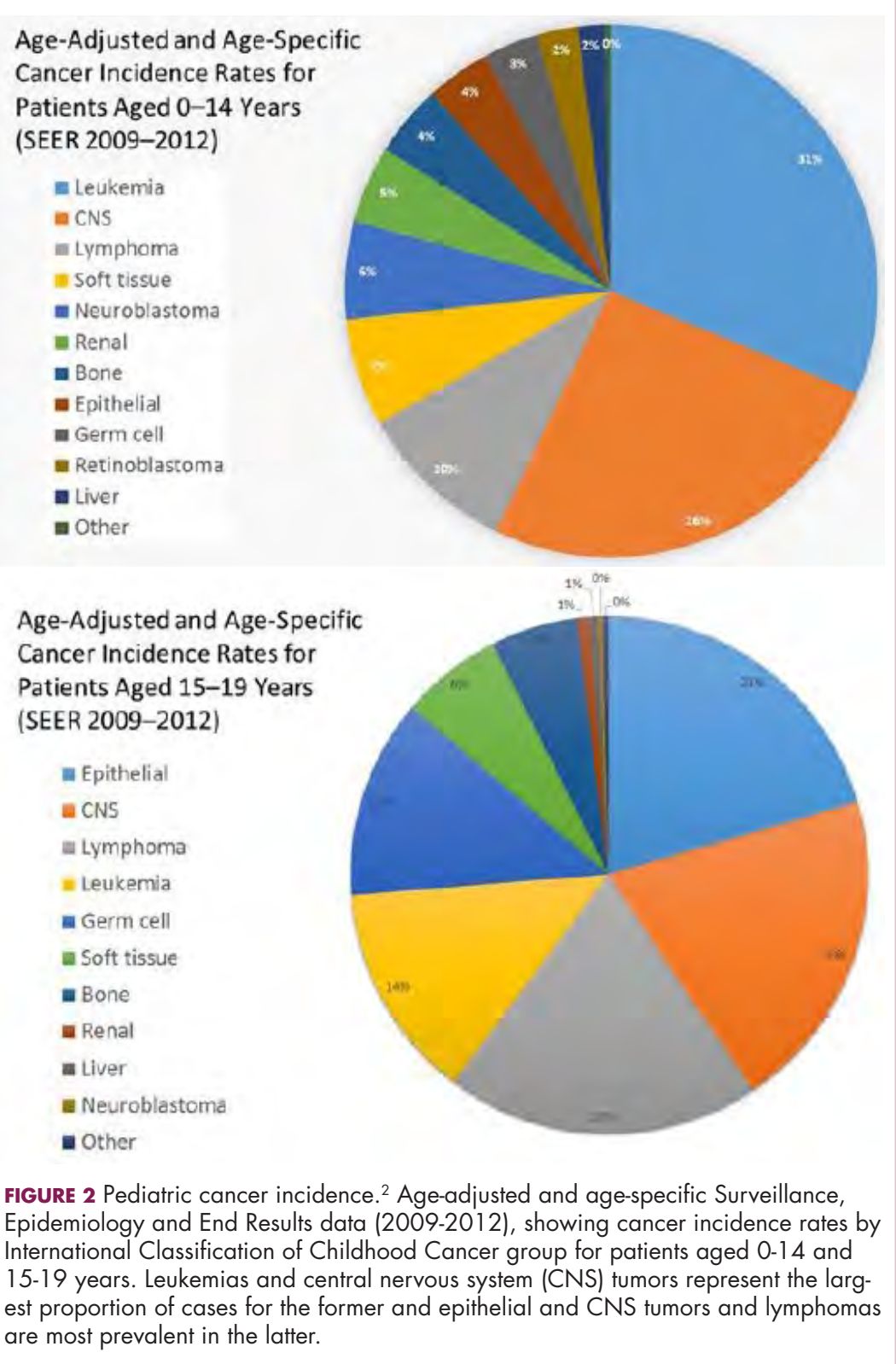

as a target, which is highly expressed on a variety of B-cell malignancies, including several of the most common forms of pediatric cancer. ASCO shined the spotlight on CAR T-cell therapy this year, naming it the Advance of the Year for 2018, saying that the treatment is "poised to transform childhood ALL." ${ }^{19}$

Two CD19-targeted CAR T-cell therapies - tisagenlecleucel and axicabtagene ciloleucel - were brought to market in 2017. Only tisagenlecleucel is approved in the pediatric ALL population, however, having been awarded approval for the treatment of patients aged up to 25 years whose disease is refractory to or relapsed after receiving at least 2 prior therapies. In the pivotal trial, complete responses were observed in more than $60 \%$ of patients. ${ }^{20}$ 
TABLE 3 Select ongoing clinical trials of immunotherapy in pediatric cancers

\begin{tabular}{|c|c|c|c|}
\hline Drug & Developer & Mechanism of action & pediatric setting (ClinicalTrials.gov identifier) \\
\hline Ibrutinib (Imbruvica) & $\begin{array}{l}\text { Pharmacyclics/ } \\
\text { Janssen }\end{array}$ & BTK Inhibitor & Phase 3 in relapsed/refractory NHL (NCT02703272) \\
\hline Blinatumomab (Blincyło) & Amgen & CD19-targeted BiTE & $\begin{array}{l}\text { Phase } 1+\text { immune checkpoint inhibitors in B-cell leukemias/ } \\
\text { lymphoma (NCT02879695, NCT03605589) }\end{array}$ \\
\hline $\begin{array}{l}\text { Brentuximab vedotin } \\
\text { (Adcetris) }\end{array}$ & Seattle Genetics & CD30-targeted ADC & $\begin{array}{l}\text { Phase } 3+\text { combination chemotherapy in high-risk cHL } \\
\text { (NCT02166463) }\end{array}$ \\
\hline $\begin{array}{l}\text { Inotuzumab ozogamicin } \\
\text { (Besponsa) }\end{array}$ & Wyeth & CD22-targeted ADC & $\begin{array}{l}\text { Phase } 3+\text { chemotherapy in newly diagnosed B-cell ALL } \\
\text { (NCT03150693) }\end{array}$ \\
\hline Pembrolizumab (Keytruda) & Merck & PDl-targeted mAb & $\begin{array}{l}\text { Phase } 3 \text { in metastatic melanoma (KEYNOTE-716; } \\
\text { NCT03553836) }\end{array}$ \\
\hline Nivolumab (Opdivo) & $\begin{array}{l}\text { Bristol-Myers } \\
\text { Squibb }\end{array}$ & PDl-targeted mAb & $\begin{array}{l}\text { Phase } 2+\text { +- ipilimumab in high-grade primary CNS malignan- } \\
\text { cies (NCT03 130959) }\end{array}$ \\
\hline
\end{tabular}

\begin{tabular}{|c|c|c|c|}
\hline Durvalumab (Imfinzi) & AstraZeneca & PDL 1-targeted mAb & $\begin{array}{l}\text { Phase } 1 \text { in relapsed/refractory solid tumors, lymphoma and } \\
\text { CNS tumors (NCT02793466) }\end{array}$ \\
\hline Tisagenlecleucel (Kymriah) & Novartis & $\begin{array}{l}\text { CD19-targeted CAR T-cell } \\
\text { therapy }\end{array}$ & Phase 2 in NHL (BIANCA; NCT03610724) \\
\hline
\end{tabular}

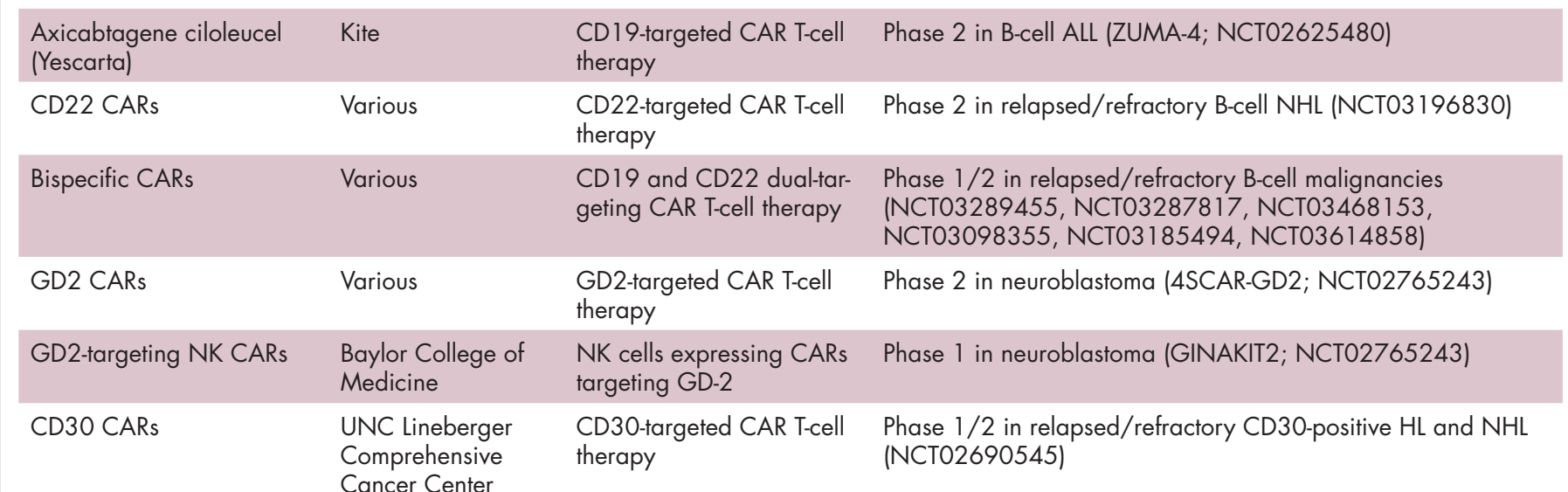

\begin{tabular}{|c|c|c|c|}
\hline HER2 CARs & $\begin{array}{l}\text { Seattle Children's } \\
\text { Hospital }\end{array}$ & $\begin{array}{l}\text { HER2-targeted CAR T-cell } \\
\text { therapy }\end{array}$ & Phase 1 in relapsed/refractory CNS tumors (NCT03500991) \\
\hline EGFR CARs & $\begin{array}{l}\text { Seattle Children's } \\
\text { Hospital }\end{array}$ & $\begin{array}{l}\text { EGFR806-targeted CAR } \\
\text { T-cell therapy }\end{array}$ & $\begin{array}{l}\text { Phase } 1 \text { in relapsed/refractory solid and CNS tumors } \\
\text { (NCT03638167, NCT03618381) }\end{array}$ \\
\hline Glypican-3 CARs & $\begin{array}{l}\text { Baylor College of } \\
\text { Medicine }\end{array}$ & $\begin{array}{l}\text { Glypican-3-targeted CAR } \\
\text { T-cell therapy }\end{array}$ & Phase 1 in solid tumors (NCT02932956) \\
\hline Dinutuximab (Unituxin) & United Therapeutics & Anti-GD2 mAb & $\begin{array}{l}\text { Phase } 2+1311-\text { MIBG in relapsed/refractory neuroblastoma } \\
\text { (NCT02932956) }\end{array}$ \\
\hline NK cells & Various & $\begin{array}{l}\text { Adoptive cell therapy } \\
\text { using donor NK cells }\end{array}$ & $\begin{array}{l}\text { Phase } 1 / 2 \text { in relapsed/refractory AML (NCT03068819, } \\
\text { NCT02763475), solid tumors (NCTO1807468*, } \\
\text { NCT03420963, NCT02100891), neuroblastoma } \\
\text { (NCT02573896) }\end{array}$ \\
\hline
\end{tabular}

ADC, antibody-drug conjugate; ALL, acute lymphoblastic leukemia; AML, acute myeloid leukemia; BiTE, bispecific T-cell engager; BTK, Bruton's tyrosine kinase; CAR, chimeric antigen receptor; cHL, classical Hodgkin lymphoma; CNS, central nervous system; EGFR, epidermal growth factor receptor; HER2, human epidermal growth factor receptor 2; mAb, monoclonal antibody; MIBG, meta-iodobenzylguanidine; NH, non-Hodgkin lymphoma; NK, natural killer; PD-1, programmed cell death protein-1 
Clinical trials of both CAR T-cell therapies in pediatric ALL and non-Hodgkin lymphoma are ongoing (Table 3).

CD19 has also proven to be a promising target for other forms of immunotherapy, including a new type of antibody known as a bispecific T-cell engager (BiTE). In 2014, blinatumomab became the first BiTE to receive regulatory approval, for the treatment of adult patients with relapsed/ refractory ALL. Blinatumomab also targets the $\mathrm{CD} 3$ protein on T cells and helps to bring cancer cells and cytotoxic immune cells into close enough proximity that an immunological synapse can be formed between the two, facilitating tumor cell killing. ${ }^{21}$

In 2016, the approved indication was expanded into the pediatric population based on the results of a phase $1 / 2$ study in which the safety and efficacy of blinatumomab were evaluated in 93 pediatric patients with relapsed/ refractory ALL. Among the 70 patients who received the recommended dose of $5 \mu \mathrm{g} / \mathrm{m}^{2}$ a day for the first 7 days, followed by $15 \mu \mathrm{g} / \mathrm{m}^{2}$ a day thereafter, $51 \%$ achieved complete remission within the first 2 cycles, $52 \%$ of whom achieved minimal residual disease (MRD). ${ }^{22}$ Most recently, the FDA expanded the indication for blinatumomab to include patients (both adults and children) who are in remission, but MRD positive. ${ }^{23}$

Despite the dramatic responses, many patients relapse after treatment with CD19-targeted CAR T cells, and researchers have uncovered numerous mechanisms of resistance. Among them is the loss of the CD19 antigen on the surface of target cells, such that a CD19-positive tumor becomes CD19negative after treatment, driving relapse. ${ }^{24-26}$

Several strategies for overcoming CD19-negative relapse are already being investigated, including the development of CD22-targeted CAR T cells and bispecific CAR T cells that target both CD19 and CD22. The results of a firstin-human trial of anti-CD22 CAR T-cell therapy were recently published. Among 21 pediatric and adult patients with relapsed/refractory B-cell ALL who were treated with either $3 \times 10^{5}$ cells $/ \mathrm{kg}, 1 \times 10^{6}$ cells $/ \mathrm{kg}$, or $3 \times 10^{6}$ cells $/ \mathrm{kg}$, complete responses were observed in $57 \%{ }^{27}$

Results from 15 pediatric patients enrolled in a trial evaluating CD22-targeted CAR T cells as salvage therapy for those who relapse after CD19-targeted CAR T cell therapy were presented at the recent Congress of the European Hematology Association in Stockholm, Sweden. Patients who had undergone a stem cell transplant received the CAR T cells at a dose of $0.9 \times 10^{5}$ cell $/ \mathrm{kg}$ and those who had not undergone a transplant received a dose of $8.2 \times 10^{5}$ cells $/ \mathrm{kg}$. At 30 days after CAR T cell infusion, the $\mathrm{CR}$ rate was $80 \%$ and the treatment was well tolerated. ${ }^{28}$

\section{More immunotherapy approvals}

The immune checkpoint inhibitors, which work by blocking inhibitory receptors on the surface of $\mathrm{T}$ cells, have also had recent approvals in pediatric patient populations.
Pembrolizumab and nivolumab, inhibitors of the programmed cell death receptor 1 (PD-1) protein, have both been approved for use in adult and pediatric patients (older than 12 years) with relapsed/refractory metastatic colorectal cancer (and other solid tumors in the case of pembrolizumab) that display defects in the mismatch repair pathway that fixes damaged DNA or in patients that have high levels of microsatellite instability. Both deficient mismatch repair and microsatellite instability-high can indicate a high mutation burden in a tumor, which may predict increased sensitivity to immunotherapy. ${ }^{29}$

The approval in pediatric patients in both of those instances, however, was not based on data in pediatric patient populations but extrapolated from adult patients. Pembrolizumab is also approved for the treatment of adults and pediatric patients with classical Hodgkin lymphoma (cHL) after 3 or more previous treatments, but once again efficacy in the pediatric population was inferred from clinical trials performed in adults. Most recently, pembrolizumab was approved for the treatment of adult and pediatric patients with relapsed or refractory primary mediastinal large B-cell lymphoma. ${ }^{30}$

Ipilimumab, which targets a different $\mathrm{T}$ cell receptor cytotoxic T lymphocyte antigen-4 (CTLA-4) - has been approved for the treatment of pediatric patients aged 12 years and older with metastatic melanoma. This expanded indication, following on from its approval in adult patients in 2011, was based on data from 2 trials in which objective responses were observed in 2 out of 17 patients, including 1 partial response that lasted 16 months. ${ }^{31}$

Finally, antibody-drug conjugates (ADC), in which tumor antigen-targeting monoclonal antibodies are conjugated to cytotoxic payloads to combine the specificity of an antibody with the cell-killing potency of chemotherapy, have also generated some recent successes in pediatric cancers.

Gemtuzumab ozogamicin is an $\mathrm{ADC}$ that targets the CD33 protein, which is highly expressed on $85 \%-90 \%$ of cases of acute myeloid leukemia (AML). In 2000, it was the first ADC to be brought to market in the United States, but it was subsequently voluntarily withdrawn by the manufacturer in 2010 after confirmatory trials failed to show a survival benefit.

Recently, a meta-analysis of gemtuzumab ozogamicin trials suggested that the drug likely does improve long-term overall survival (OS) and reduce the risk of relapse and researchers developed an intermittent dosing schedule to help mitigate toxicity. ${ }^{32}$ This new dosing regimen received FDA approval in 2017 for the treatment of pediatric patients aged 2 years and older on the basis of 2 clinical trials.

In the MyloFrance- 1 trial, 57 patients were administered $3 \mathrm{mg} / \mathrm{m}^{2}$ gemtuzumab ozogamicin on days 1 , 4 , and 7 followed by cytarabine consolidation therapy and demonstrated a $26 \%$ CR rate and median recurrence-free survival of 11.6 months. In the phase $3 \mathrm{AML}-19$ trial, 237 patients received gemtuzumab ozogamicin at a dose of $6 \mathrm{mg} / \mathrm{m}^{2}$ on day 1 and 
$3 \mathrm{mg} / \mathrm{m}^{2}$ on day 8 or best supportive care. Gemtuzumab ozogamicin improved OS from 3.6 to 4.9 months. ${ }^{33,34}$

Inotuzumab ozogamicin is a CD22-targeting ADC that has been FDA approved for the treatment of adult patients with relapsed/refractory B-cell precursor ALL since last year. The therapy has been available to pediatric patients through

\section{References}

1. American Cancer Society. Key statistics for childhood cancers. https:// www.cancer.org/cancer/cancer-in-children/key-statistics.html. Last revised September 10, 2018. Accessed September 16, 2018.

2. NHI/National Cancer Institute website. Unusual cancers of childhood treatment (PDQ) - Health Professional Version. https://www.cancer. gov/types/childhood-cancers/hp/unusual-cancers-childhood-pdq. Last updated August 28, 2018. Accessed September 8, 2018.

3. Siegel RL, Miller KD, Jemal A. Cancer statistics, 2018. CA Cancer J Clin. 2018;68(1):7-30.

4. Marshall GM, Carter DR, Cheung BB, et al. The prenatal origins of cancer. Nat Rev Cancer. 2014;14(4):277-289.

5. Vogelstein B, Papadopoulos N, Velculescu VE, Zhou S, Diaz LA, Jr, Kinzler KW. Cancer genome landscapes. Science. 2013;339(6127):1546-1558.

6. Ma X, Liu Y, Liu Y, et al. Pan-cancer genome and transcriptome analyses of 1,699 paediatric leukaemias and solid tumours. Nature. 2018;555:371.

7. Dupain C, Harttrampf AC, Urbinati G, Geoerger B, MassaadMassade L. Relevance of fusion genes in pediatric cancers: toward precision medicine. Molec Ther Nucleic Acids. 2017;6:315-326.

8. Lemonick MD, Park A. New hope for cancer. http://content.time. com/time/world/article/0,8599,2047900-2,00.html. Published May 28, 2001. Last accessed September 13, 2018.

9. Iqbal N, Iqbal N. Imatinib: a breakthrough of targeted therapy in cancer. https://www.hindawi.com/journals/cherp/2014/357027/. Published May 19, 2014. Accessed September 16, 2018.

10. Gore L, Kearns PR, Martino MLd, et al. Dasatinib in pediatric patients with chronic myeloid leukemia in chronic phase: results from a phase II trial. J Clin Oncol. 2018;36(13):1330-1338.

11. Novartis press release. Novartis drug Tasigna approved by FDA to treat children with rare form of leukemia. 2018; https://www.novartis.com/news/media-releases/novartis-drug-tasignar-approvedfda-treat-children-rare-form-leukemia. Released March 22, 2018. Accessed September 16, 2018.

12. Takita J. The role of anaplastic lymphoma kinase in pediatric cancers Cancer Sci. 2017;108(10):1913-1920.

13. Turner SD, Lamant L, Kenner L, Brugieres L. Anaplastic large cell lymphoma in paediatric and young adult patients. Br J Haematol. 2016;173(4):560-572.

14. Antonescu CR, Suurmeijer AJH, Zhang L, et al. Molecular characterization of inflammatory myofibroblastic tumors with frequent ALK and ROS1 fusions and rare novel RET gene rearrangement. Am J Surg Pathol. 2015;39(7):957-967.

15. Mosse YP, Voss SD, Lim MS, et al. Targeting ALK with crizotinib in pediatric anaplastic large cell lymphoma and inflammatory myofibroblastic tumor: a children's oncology group study. J Clin Oncol. 2017;35(28):3215-3221.

16. Amatu A, Sartore-Bianchi A, Siena S. NTRK gene fusions as novel targets of cancer therapy across multiple tumour types. https://www. ncbi.nlm.nih.gov/pmc/articles/PMC5070277/. Published online March 18, 2016. Accessed September 16, 2018.

17. [Behind paywall.] Laetsch TW, DuBois SG, Mascarenhas L, et al. Larotrectinib for paediatric solid tumours harbouring NTRK gene fusions: phase 1 results from a multicentre, open-label, phase 1/2 study. Lancet Oncol. 2018;19(5):705-714.

18. Desai AV, Brodeur GM, Foster J, et al. Phase 1 study of entrectinib (RXDX-101), a TRK, ROS1, and ALK inhibitor, in children, adolescents, and young adults with recurrent or refractory solid tumors. J Clin Oncol. 2018;36(suppl;):abstr 10536.

19. Heymach J, Krilov L, Alberg A, et al. Clinical cancer advances 2018: a compassionate access program, but it has not been extensively evaluated in this population. The results of a retrospective analysis of pediatric patients who received at least 1 dose of inotuzumab ozogamicin were presented at ASCO in 2017. Among 29 patients with heavily pretreated disease the CR rate was $62 \%, 72 \%$ of whom achieved MRD negativity. ${ }^{35}$

annual report on progress against cancer from the American Society of Clinical Oncology. J Clin Oncol. 2018;36(10):1020-1044.

20. Maude SL, Laetsch TW, Buechner J, et al. Tisagenlecleucel in children and young adults with B-cell lymphoblastic leukemia. NEJM. 2018;378(5):439-448.

21. Wu J, Fu J, Zhang M, Liu D. Blinatumomab: a bispecific T cell engager (BiTE) antibody against CD19/CD3 for refractory acute lymphoid leukemia. J Hematol Oncol. 2015;8:104.

22. Stackelberg Av, Locatelli F, Zugmaier G, et al. Phase I/phase II study of blinatumomab in pediatric patients with relapsed/refractory acute lymphoblastic leukemia. J Clin Oncol. 2016;34(36):4381-4389.

23. Gokbuget N, Dombret H, Bonifacio M, et al. Blinatumomab for minimal residual disease in adults with B-cell precursor acute lymphoblastic leukemia. Blood. 2018;131(14):1522-1531.

24. Fischer J, Paret C, E1 Malki K, et al. CD19 isoforms enabling resistance to CART-19 immunotherapy are expressed in B-ALL patients at initial diagnosis. J Immunother. 2017;40(5):187-195.

25. Fousek K, Watanabe J, George A, et al. Targeting CD19-negative relapsed $\mathrm{B}$-acute lymphoblastic leukemia using trivalent CAR T cells. J Clin Oncol. 2018;36(5_suppl):121-121.

26. Mejstríková E, Hrusak O, Borowitz MJ, et al. CD19-negative relapse of pediatric B-cell precursor acute lymphoblastic leukemia following blinatumomab treatment. Blood Cancer J. 2017;7(12):659.

27. Fry TJ, Shah NN, Orentas RJ, et al. CD22-targeted CAR T cells induce remission in B-ALL that is naive or resistant to CD19targeted CAR immunotherapy. Nat Med. 2018;24(1):20-28.

28. Pan J, Deng B, Liu S, et al. Efficacy and safety of CD22-directed CAR T-cell therapy in 15 pediatric refractory or relapsed $b$ acute lymphoblastic leukemia patients. Paper presented at 23rd Congress of the European Hematology Association 2018; Stockholm, Sweden.

29. Boyiadzis MM, Kirkwood JM, Marshall JL, Pritchard CC, Azad NS, Gulley JL. Significance and implications of FDA approval of pembrolizumab for biomarker-defined disease. J Immunother Cancer. 2018;6:35.

30. Drugs.com. Keytruda approval history. 2018; https://www.drugs. $\mathrm{com} /$ history/keytruda.html. Last update information not given. Accessed September 16, 2018.

31. Bristol Myers Squibb press release. US Food and Drug Administration expands approval of Yervoy (ipilimumab) to include pediatric patients 12 years and older with unresectable or metastatic melanoma. https://news.bms.com/press-release/corporatefinancialnews/us-food-and-drug-administration-expands-approval-yervoyipilim. Released July 24, 2017. Accessed September 16, 2018.

32. Hills RK, Castaigne S, Appelbaum FR, et al. Addition of gemtuzumab ozogamicin to induction chemotherapy in adult patients with acute myeloid leukaemia: a meta-analysis of individual patient data from randomised controlled trials. Lancet Oncol. 2014;15(9):986-996.

33. Amadori S, Suciu S, Selleslag D, et al. Gemtuzumab ozogamicin versus best supportive care in older patients with newly diagnosed acute myeloid leukemia unsuitable for intensive chemotherapy: results of the randomized phase III EORTC-GIMEMA AML-19 trial. J Clin Oncol. 2016;34(9):972-979.

34. Taksin AL, Legrand O, Raffoux E, et al. High efficacy and safety profile of fractionated doses of Mylotarg as induction therapy in patients with relapsed acute myeloblastic leukemia: a prospective study of the alfa group. Leukemia. 2007;21(1):66-71.

35. Bhojwani D, Sposto R, Shah N, et al. Inotuzumab ozogamicin in pediatric patients with relapsed/refractory acute lymphoblastic leukemia (R/R ALL). J Clin Oncol. 2017;35(15_suppl):10512-10512. 